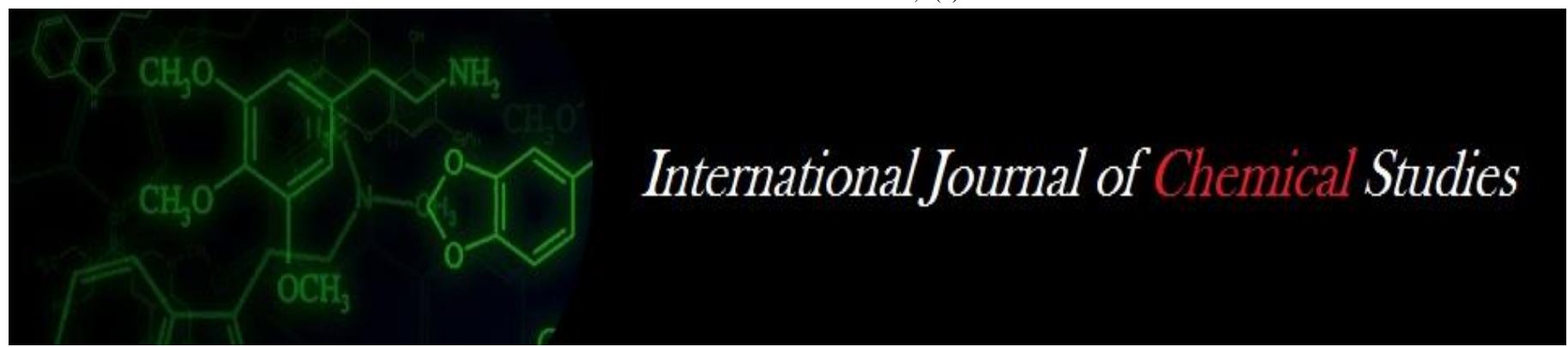

P-ISSN: 2349-8528

E-ISSN: 2321-4902

www.chemijournal.com

IJCS 2020; 8(3): 2293-2296

(C) 2020 IJCS

Received: 04-03-2020

Accepted: 06-04-2020

\section{Mayuri Thakur}

Department of Agronomy, BTC

CARS, Bilaspur (C.G.), IGKV,

Raipur, Chhattisgarh, India

\section{HP Agrawal}

Department of Agronomy, BTC CARS, Bilaspur (C.G.), IGKV

Raipur, Chhattisgarh, India

\section{JR Patel}

Department of Agronomy, BTC CARS, Bilaspur (C.G.), IGKV,

Raipur, Chhattisgarh, India

\section{Ritesh Kumar Singh}

Department of Agronomy, BTC

CARS, Bilaspur (C.G.), IGKV,

Raipur, Chhattisgarh, India

\section{Sumit}

Department of Agronomy,

College of Agriculture, IGKV,

Raipur, Chhattisgarh, India
Corresponding Author:

Mayuri Thakur

Department of Agronomy, BTC

CARS, Bilaspur (C.G.), IGKV,

Raipur, Chhattisgarh, India

\section{Effect of bio-inoculant, organic manure and chemical fertilizer on growth and yield of wheat (Triticum aestivum L.)}

\author{
Mayuri Thakur, HP Agrawal, JR Patel, Ritesh Kumar Singh and Sumit
}

DOI: https://doi.org/10.22271/chemi.2020.v8.i3ag.9550

\begin{abstract}
An experiment was conducted during Rabi season 2018-19 at Instructional Farm, BTC College of Agriculture and Research Station, Bilaspur to to study the effect of bio-inoculant, organic manure and chemical fertilizer on growth and yield of wheat (Triticum aestivum L.). The wheat (var. CG-1013) was grown and treatments were replicated three times in randomized block design. The experiment consists of twelve treatments viz., 100\% RDF (T1), 75\% RDF (T2), 75\% RDF + FYM @ $5 \mathrm{t} \mathrm{ha}^{-1}$ (T3), 75\% RDF + Azotobacter (T4), 75\% RDF + FYM @ $5 \mathrm{t} \mathrm{ha}^{-1}+$ Azotobacter (T5), 75\% RDF + Azotobacter + PSB (T6), 75\% RDF + FYM @ $5 \mathrm{tha}^{-1}+$ Azotobacter + PSB (T7), 50\% RDF + FYM @ $5 \mathrm{t} \mathrm{ha}^{-1}$ (T8), 50\% $\mathrm{RDF}+$ Azotobacter (T9), 50\% RDF + FYM @ $5 \mathrm{t} \mathrm{ha}^{-1}+$ Azotobacter (T10), 50\% RDF + Azotobacter + PSB (T11), 50\% RDF + FYM @ $5 \mathrm{t} \mathrm{ha}^{-1}+$ Azotobacter + PSB (T12). The soil of the experimental field was clay in texture. The result revealed that growth parameters viz., plant population $\left(\mathrm{m}^{-2}\right)$, plant height $(\mathrm{cm})$, number of tillers $\left(\mathrm{m}^{-2}\right)$, number of effective tillers $\left(\mathrm{m}^{-2}\right)$ and dry matter accumulation $\left(\mathrm{g} \mathrm{plant}^{-1}\right)$ were recorded maximum with the application of $100 \%$ RDF (T1) which was at par with the application of 75\% RDF + FYM @ $5 \mathrm{t} \mathrm{ha}^{-1}+$ Azotobacter + PSB (T7) and was significantly superior over all treatments at all stages of observations. The improvement in yield attributes and yield of wheat was recorded with the application of $100 \% \mathrm{RDF}$ (T1) which was at par with the application of $75 \% \mathrm{RDF}+$ FYM @ $5 \mathrm{t} \mathrm{ha}^{-1}+$ Azotobacter + PSB (T7).
\end{abstract}

Keywords: Wheat, Azotobacter, PSB, FYM, RDF, yield, yield attributes

\section{Introduction}

Wheat (Triticum aestivum L.) is one of the most extensively grown cereal crop worldwide that has been known as the "king of cereals" emanating as the keystone of India's food security and depicts the primary food for about one third of the world population. The production capability is highly versatile among wide range of agro ecological regions throughout the country, due to variable genotypes, climatic conditions, seeding time and practices and other management practices. It exceeds in hectarage and production, occupying a remarkable position among all other grain crops serving as a life sustaining crop. On the global context, India is the second largest producer of wheat with approximately $12 \%$ world's wheat production and it is also the second largest consumer of wheat after China, and has a huge growing demand. Wheat has occupied an area of $222.01 \mathrm{mha}$, with a total production of $753.31 \mathrm{mt}$ and productivity $3.39 \mathrm{t}$ ha-1 (USDA, 2017) in world. In India, wheat has covered an area of 30.785 mha, with a total production of $98.510 \mathrm{mt} \mathrm{ha}^{-1}$ and productivity $3.2 \mathrm{mt} \mathrm{ha}^{-1}$. In terms of world acreage, India stands next to China while it ranks second in respect of production. During the year of 2017 2018, India has exported $322790.14 \mathrm{mt}$ of wheat to the world for the worth of ₹ 624.37 crores. Integrated nutrient management involves the integrated use of mineral fertilizers together with organic manure where inclusion of organic manures improves physical properties, soil fertility and crop yields. Organic manure when applied in combination with biofertilizers, supplies energy to beneficial micro-organism including Azotobacter and PSB, also used for mitigating the multiple nutrient deficiencies. Nitrogen is a principal structural nutrient of the cell along with phosphorus and potassium which helps in building up vegetative growth of plant while phosphorus and potassium is required for better crop production, photosynthesis and translocation of nutrients from leaves to the seed respectively. Therefore application of adequate amount of nutrients is a required key to obtain the bumper crop of wheat. 
On account of continuing world energy crisis, inflation in chemical fertilizer and the lower purchasing power of most of the farming community limits its use in proper amount, hampering crop production due to which the use of organic manure as a renewable source of plant nutrients is attaining importance. In this venture, proper blend of organic manure, biofertilizer and inorganic fertilizer is a good substitute not only for increasing yield but also for sustaining soil physico chemical and biological properties. FYM recoup the soil health and decrease mineral fertilizer requirement while biofertilizer help in improving crop productivity by increasing biological nitrogen fixation. Efficient input management along with varietal improvement is the two fundamental features that can help us in accomplishing the goal. Considering the above facts, present investigation was carried to find out the effect of bio-inoculant, organic manure and chemical fertilizer on growth and yield of wheat.

\section{Material and Methods}

A field experiment was conducted at the Instructional Farm, BTC College of Agriculture and Research Station, Bilaspur, Chhattisgarh during Rabi season of year 2018-19. The experiment laid out in randomized block design with three replications. The soil of the experimental field was neutral in reaction 6.9 and clay (vertisol) in texture. The soil was categorized as medium inorganic carbon $(0.75 \%)$, low in available nitrogen $\left(275 \mathrm{~kg} \mathrm{ha}^{-1}\right)$ and medium in available phosphorus (13.75 $\left.\mathrm{kg} \mathrm{ha}^{-1}\right)$, Potassium content $\left(268 \mathrm{~kg} \mathrm{ha}^{-1}\right)$ organic carbon $(0.75 \%)$ and electrical conductivity $(0.21 \mathrm{dS}$ $\mathrm{m}^{-1}$ at $\left.25{ }^{\circ} \mathrm{C}\right)$. The total treatment combinations were twelve. The treatment details are $100 \%$ recommended dose of fertilizer (RDF) (T1), 75\% RDF (T2), 75\% RDF + FYM @ 5 $\mathrm{t} \mathrm{ha}^{-1}$ (T3), 75\% RDF + Azotobacter (T4), 75\% RDF + FYM @ $5 \mathrm{t} \mathrm{ha}^{-1}+$ Azotobacter (T5), 75\% RDF + Azotobacter + PSB (T6), 75\% RDF + FYM @ $5 \mathrm{t} \mathrm{ha}^{-1}+$ Azotobacter + PSB (T7), 50\% RDF + FYM @ $5 \mathrm{t} \mathrm{ha}^{-1}$ (T8), 50\% RDF + Azotobacter (T9), 50\% RDF + FYM @ $5 \mathrm{t} \mathrm{ha}^{-1}+$ Azotobacter (T10), 50\% RDF + Azotobacter + PSB (T11), 50\% RDF + FYM @ $5 \mathrm{t} \mathrm{ha}^{-1}+$ Azotobacter + PSB (T12) were applied. CG1013 variety were sown by line sowing method with a row spacing of $20 \mathrm{~cm}$ apart and seed rate was $100 \mathrm{~kg} \mathrm{ha}^{-1}$. The recommended dose of fertilizers for wheat are $120,60,40 \mathrm{~kg}$ of $\mathrm{N}, \mathrm{P}_{2} \mathrm{O}_{5}, \mathrm{~K}_{2} \mathrm{O}$ ha ${ }^{-1}$ respectively. Full dose of $\mathrm{P}_{2} \mathrm{O}_{5}, \mathrm{~K}_{2} \mathrm{O}$ and $50 \%$ of Nitrogen were applied at the time of sowing. The remaining nitrogen as per treatment was top dressed after first irrigation. The amount of organic manure Azotobacter and PSB were applied as per treatment wise. The field was kept free from weeds by manual hoeing. Plant protection measures and irrigations whenever required were provided in same manner for all the treatments. Regular biometric observations were recorded at periodic intervals of $30 \mathrm{DAS}, 60 \mathrm{DAS}, 90$ DAS and at harvest stage of selected plants. Growth parameters were recorded just before harvesting of crop. Harvesting was done when the spikes matured and plant was dried up. Thus grain yield of each plot was recorded as $\mathrm{kg}$ plot $^{-1}$ and then converted into $\mathrm{q} \mathrm{ha}^{-1}$ after that threshing of the crop was done with thresher and straw was collected separately. Statistical data were analyzed by standard procedure by Gomez and Gomez (1984) ${ }^{[2]}$.

\section{Results and Discussion \\ Effect on Growth Characters}

The result of the present study indicated that growth parameters of plant such as plant height, number of green leaves per plant, number of tillers $\left(\mathrm{m}^{-2}\right)$, dry matter accumulation $\left(\mathrm{g}\right.$ plant $\left.{ }^{-1}\right)$ of wheat crop was significantly influenced by different integrated nutrient management treatments. Among the integrated nutrient management treatment, the maximum plant height was recorded with the application of $100 \%$ RDF (T1) which was at par with the application of $75 \% \mathrm{RDF}+\mathrm{FYM} @ 5 \mathrm{tha}^{-1}+$ Azotobacter + PSB (T7) and was significantly superior over all treatments at all stages of observations. The height of plant was recorded least in the application of 50\% RDF + Azotobacter (T9). The reason for higher values of growth parameter were examined in the view of the foregoing fact that crop under these treatments relatively more nutrient available in the field for plants and thereby more availability of nutrients which resulted in better crop growth and ultimately more dry matter accumulation which might be due to application of organic matter and biofertilizer, help in nutrient mobility and therefore plant uptake more nutrients by reducing nutrient losses through leaching runoff etc. The dry matter production increase due to greater number of tillers and addition of more photosynthates under the influence of more nutrient availability. These results were supported by Singh et al., 2018 and Parewa et al., $2018^{[8,5]}$.

Table 1: Effect of different treatments on growth attributes parameters of wheat.

\begin{tabular}{|c|c|c|c|c|c|c|c|c|c|c|c|c|c|}
\hline \multirow{2}{*}{\multicolumn{2}{|c|}{ Treatment }} & \multicolumn{4}{|c|}{ Plant Height (cm) } & \multicolumn{4}{|c|}{$\begin{array}{c}\text { Dry matter accumulation } \\
\left(\mathrm{g}^{\text {glant }}{ }^{-1}\right)\end{array}$} & \multicolumn{4}{|c|}{ Number of tillers $\left(\mathrm{m}^{-2}\right)$} \\
\hline & & \multirow{3}{*}{\begin{tabular}{|c|}
$\mathbf{3 0}$ \\
DAS \\
38.20 \\
\end{tabular}} & \multirow{2}{*}{\begin{tabular}{|c|}
60 \\
DAS \\
\end{tabular}} & \multirow{2}{*}{$\begin{array}{c}90 \\
\text { DAS }\end{array}$} & \multirow{2}{*}{$\begin{array}{c}\text { At } \\
\text { harvest }\end{array}$} & \multirow{2}{*}{$\begin{array}{c}\text { 30 } \\
\text { DAS }\end{array}$} & \multirow{2}{*}{$\begin{array}{c}\text { 60 } \\
\text { DAS }\end{array}$} & \multirow{2}{*}{$\begin{array}{c}90 \\
\text { DAS }\end{array}$} & \multirow{2}{*}{$\begin{array}{c}\text { At } \\
\text { harvest }\end{array}$} & \multirow{2}{*}{\begin{tabular}{|c|} 
30 \\
DAS
\end{tabular}} & \multirow{2}{*}{\begin{tabular}{|c|} 
60 \\
DAS \\
\end{tabular}} & \multirow{3}{*}{\begin{tabular}{|c}
$\begin{array}{c}\mathbf{9 0} \\
\text { DAS }\end{array}$ \\
40733
\end{tabular}} & \multirow{3}{*}{\begin{tabular}{|c|}
$\begin{array}{c}\text { At } \\
\text { harvest }\end{array}$ \\
391.67 \\
\end{tabular}} \\
\hline & & & & & & & & & & & & & \\
\hline $\mathrm{T} 1$ & 100\% RDF (120:60:40 N:P:K kg ha-1) & & & 98.80 & 97.80 & 0.67 & 65.76 & 54.74 & 28.00 & 214.93 & 378.26 & & \\
\hline $\mathrm{T} 2$ & & 34.73 & & 92.47 & & & 61.38 & 51.02 & 4.90 & & & & \\
\hline $\mathrm{T} 3$ & $75 \% \mathrm{RDF}+\mathrm{FI}$ & 35.80 & & 94.07 & 93. & 61 & 62.82 & 52.41 & 26.88 & 206.07 & & 40 & 385.07 \\
\hline $\mathrm{T} 4$ & $75 \% \mathrm{RDF}+$ & 34.87 & 68.40 & 92.93 & 92. & 0.57 & 61.94 & 51.60 & 24.96 & & & 393.19 & 378.19 \\
\hline $\mathrm{T} 5$ & 75\%RDF+FYM @ 5 t ha ${ }^{-1}+$ Azotobacter & 36.60 & 72.93 & 96.93 & 94.33 & 0.62 & 63.96 & 52.97 & 27.39 & 207.79 & 371 & & 386.46 \\
\hline T6 & & 34.93 & & 93.47 & & & 62.21 & 51.80 & & & & & \\
\hline $\mathrm{T} 7$ & $75 \% \mathrm{RDF}+\mathrm{FYM} @ 5 \mathrm{t} \mathrm{ha}^{-1}+A$ & 37.27 & & 98.73 & 97.67 & 65 & 65.68 & 54.67 & & & & & 389.59 \\
\hline T8 & $50 \% \mathrm{RDF}+\mathrm{FY}$ & 33.20 & & 91.73 & 90.46 & 0.50 & 60.90 & 50.62 & 24.30 & 194.82 & & 386.07 & 372.56 \\
\hline T9 & $50 \% \mathrm{RDF}+$ Azotobacter & 31.07 & 62.73 & 90.67 & 89.67 & 0.46 & 60.27 & 50.13 & 23.89 & 186.15 & 352.48 & 380.48 & 365.48 \\
\hline T10 & 50\%RDF+FYM @ $5 \mathrm{t} \mathrm{ha}^{-1}+$ Azotobacter & 33.73 & 65.67 & 92.33 & 91.00 & 0.53 & 61.29 & 50.94 & 24.89 & 196.74 & 359.07 & 387.90 & 374.07 \\
\hline T11 & $50 \% \mathrm{RDF}+$ Azotobacter $+\mathrm{PSB}$ & 32.20 & 64.33 & 91.00 & 90.33 & 0.49 & 60.61 & 50.48 & 24.25 & 191.95 & 354.95 & 384.29 & 369.29 \\
\hline T12 & $50 \%$ RDF + FYM @ 5 $\mathrm{t} \mathrm{ha}^{-1}+$ Azotobacter + PSB & 35.60 & 69.13 & 93.67 & 93.50 & 0.59 & 62.59 & 52.23 & 26.50 & 204.01 & 367.67 & 399.01 & 383.01 \\
\hline & & 0.93 & 2.53 & 1.77 & 1.52 & 0.05 & 0.43 & 0.61 & & 1.32 & & & 1.87 \\
\hline & $\mathrm{CD}(\mathrm{P}=0.05)$ & 2.73 & 7.43 & 5.18 & 4.44 & NS & 1.27 & 1.78 & 2.57 & 3.88 & 4.80 & 5.81 & 5.49 \\
\hline
\end{tabular}




\section{Effect on Yield Attributes}

Yield attributes, which determine yield, is the resultant of the vegetative development of the plant. The data presented in Table 2 revealed that effect of different nutrient management treatments on effective tillers $\mathrm{m}^{-2}$, number of grains ear ${ }^{-1}$ head, weight of grains ear ${ }^{-1}$ and test weight of wheat was found significant. The treatment comprising application of $100 \%$ RDF (T1) produced significantly higher number of effective tillers (383.3) over all other treatments, while treatments T7 and T5 exhibited on par performance for number of effective tillers. Minimum number of tillers was recorded significantly from the treatment 50\% RDF with Azotobacter (359.5). The increase in number of tillers in $\mathrm{T} 1$ was by $6.20 \%$ compared to $\mathrm{T} 7$. The treatment $\mathrm{T} 1$ was found highest number of grains per ear head. The number of grains per ear head varied from 59.3 3 (T1) and to 52.93 (T9). Treatment T1 (100\% RDF) was at par with T7 (75\% RDF + FYM @ $5 \mathrm{t} \mathrm{ha}^{-1}+$ Azotobacter + PSB) followed by T5 (75\% RDF + FYM @ $5 \mathrm{t} \mathrm{ha}^{-1}+$ Azotobacter), T3 (75\% RDF + FYM @ 5 t ha-1), T12 (50\% $\mathrm{RDF}+\mathrm{FYM} @ 5 \mathrm{t} \mathrm{ha}^{-1}+$ Azotobacter + PSB) and T6 $(75 \%$ $\mathrm{RDF}+$ Azotobacter + PSB), while it was significantly superior over other treatments. The maximum grain weight (2.69 $\mathrm{g} \mathrm{ear}^{-1}$ ) was recorded in treatment $\mathrm{T} 1$ closely followed by T7, T5, T3, T6 and T12. Treatment comprising application of 50\% NPK with Azotobacter recorded lowest grain weight (2.06 $\left.\mathrm{g} \mathrm{ear}^{-1}\right)$. Application of $100 \% \mathrm{RDF}$ was found superior compared to integrated use of $50 \%$ RDF, FYM and biofertilizers. Application of $100 \%$ recommended dose of fertilizer recorded higher test weight $45.29 \mathrm{~g}$ (T1), being statistically similar with treatments T7, T5, T3, T12 and T6. Comparing with other fertilizer treatments, the 1000 grain weight was significantly lower in treatments where recommended fertilizer dose was below 50\%. Treatment comprising 50\% RDF + Azotobacter recorded lower test weight (38.95 g). However, spike length was nonsignificantly improved by different treatments. The enhancement in number of tillers might be due to increase in stimulation of vegetative growth of the plant. The increase in effective tillers $\mathrm{m}^{-2}$, number of grains ear $^{-1}$ head, weight of grains ear ${ }^{-1}$ and test weight with the combined use of fertilizer, organic manure and bio-inoculant was attributed that it might be due to additive effect of nitrogen fixing ability of biofertilizers from the atmosphere along with the synthesis of certain plant growth regulators such as auxin and gibberellin by Azotobacter while FYM proved to be more beneficial due to gradual mineralization and availability of nutrients along with moisture holding capacity of soil by FYM. Similar results were reported by Parewa et al., (2018), Jaga et al., (2017) and Kakraliya et al., (2018) ${ }^{[5,3,4]}$.

\section{Effect on Yield}

Grain $\left(\mathrm{q} \mathrm{ha}^{-1}\right)$ and straw yield $\left(\mathrm{q} \mathrm{ha}^{-1}\right)$ were significantly affected by different treatments. It increases with increasing level of nutrient (NPK) upto 100\% RDF applied alone or in combination with organic source (FYM). The highest grain yield was recorded with the application of $100 \%$ RDF (T1) which was at par with T7, T5, T3, T12 and T6. While it was significantly superior over other treatment. Similarly, straw yield was also significantly more under T1 than rest of the treatments except T7, T5, T3, T12 and T6. The improvement in grain yield and straw yield is having $22.66 \%$ and $18 \%$ in $100 \%$ RDF (T1) as compared to 50\% RDF + Azotobacter (T9). For these reasons, higher growth attributes contributes higher yield. The incorporation of inorganic source of nutrients, organic manure and biofertilizers might have supplied readily available nutrients which result in greater assimilation, production and partitioning of dry matter, thereby increasing the yield. Tejalben et al., (2017) ${ }^{[7]}$ also observed that increase in yield was possibly due to the higher amount of organic carbon help in improving physicochemical properties of soil. The similar results were found by Rather and Sharma (2009) and Chaudhary et al., (2017) ${ }^{[6,1]}$.

Table 2: Effect of different treatments on yield attributes and yield parameters of wheat

\begin{tabular}{|c|c|c|c|c|c|c|c|}
\hline \multicolumn{2}{|r|}{ Treatments } & \multirow{2}{*}{\begin{tabular}{|c|}
$\begin{array}{c}\text { Spike } \\
\text { Length }(\mathbf{c m})\end{array}$ \\
10.48 \\
\end{tabular}} & \multirow{2}{*}{$\begin{array}{c}\begin{array}{c}\text { No. of } \\
\text { grains ear }^{-1} \text { head }\end{array} \\
48.33\end{array}$} & \multirow{2}{*}{\begin{tabular}{|c|}
$\begin{array}{c}\text { Weight } \\
\text { of grains ear }^{-1}\end{array}$ \\
2.49 \\
\end{tabular}} & \multirow{2}{*}{\begin{tabular}{|c|}
$\begin{array}{c}\text { Test } \\
\text { Weight (g) }\end{array}$ \\
43.79 \\
\end{tabular}} & \multirow{2}{*}{\begin{tabular}{|c|}
$\begin{array}{c}\text { Grain Yield } \\
\left(\mathbf{q} \text { ha }^{-1}\right)\end{array}$ \\
44.23 \\
\end{tabular}} & \multirow{2}{*}{\begin{tabular}{|c}
$\begin{array}{c}\text { Straw yield } \\
\left(\mathbf{q} \mathbf{h a}^{-\mathbf{1}}\right)\end{array}$ \\
42.91 \\
\end{tabular}} \\
\hline T1 & 100\% RDF (120:60:40 N:P:K kg ha-1) & & & & & & \\
\hline $\mathrm{T} 2$ & $75 \% \mathrm{RDF}$ & 9.35 & 43.80 & 2.11 & 40.37 & 39.85 & 39.04 \\
\hline T3 & 75\% RDF + FYM @ $5 \mathrm{t} \mathrm{ha}^{-1}$ & 9.53 & 46.40 & 2.23 & 40.84 & 41.70 & 42.17 \\
\hline $\mathrm{T} 4$ & $75 \% \mathrm{RDF}+$ Azotobacter & 9.48 & 44.00 & 2.14 & 40.42 & 40.19 & 40.21 \\
\hline $\mathrm{T5}$ & 75\%RDF+FYM @ $5 \mathrm{t} \mathrm{ha}^{-1}+$ Azotobacter & 9.57 & 46.73 & 2.25 & 41.92 & 42.76 & 42.15 \\
\hline T6 & $75 \%$ RDF + Azotobacter + PSB & 9.50 & 45.67 & 2.16 & 40.59 & 40.37 & 40.24 \\
\hline $\mathrm{T} 7$ & 75\% RDF + FYM @ $5 \mathrm{t} \mathrm{ha}^{-1}+$ Azotobacter + PSB & 10.42 & 47.00 & 2.38 & 43.06 & 43.51 & 42.57 \\
\hline T8 & $50 \%$ RDF + FYM @ $5 \mathrm{t} \mathrm{ha}^{-1}$ & 9.27 & 42.13 & 2.03 & 39.78 & 37.15 & 38.69 \\
\hline T9 & $50 \% \mathrm{RDF}+$ Azotobacter & 9.05 & 41.93 & 1.93 & 37.45 & 36.06 & 37.61 \\
\hline T10 & 50\%RDF+FYM @ $5 \mathrm{t} \mathrm{ha}^{-1}+$ Azotobacter & 9.32 & 43.33 & 2.08 & 40.23 & 38.06 & 39.43 \\
\hline T11 & $50 \% \mathrm{RDF}+$ Azotobacter $+\mathrm{PSB}$ & 9.07 & 42.00 & 2.00 & 38.48 & 36.58 & 38.19 \\
\hline T12 & 50\% RDF + FYM @ $5 \mathrm{t} \mathrm{ha}^{-1}+$ Azotobacter + PSB & 9.52 & 45.80 & 2.21 & 40.75 & 40.61 & 39.52 \\
\hline & SEm $( \pm)$ & 0.37 & 1.13 & 0.10 & 1.11 & 1.34 & 1.11 \\
\hline & $\mathrm{CD}(\mathrm{P}=0.05)$ & 1.10 & 3.32 & 0.31 & 3.25 & 3.93 & 3.24 \\
\hline
\end{tabular}

\section{Conclusion}

On the basis of results summarized above, it can be concluded that balanced use of plant nutrients from both organic and inorganic sources along with biofertilizers strengthened the nutrient availability and the growth and yield of wheat. Application of $100 \%$ RDF (T1) gave best results in respect to all growth, yield and yield attributing parameters and second best treatment is $75 \% \mathrm{RDF}+\mathrm{FYM} @ 5 \mathrm{t} \mathrm{ha}^{-1}+$ Azotobacter + PSB (T7).

\section{References}

1. Choudhary RR, Yadav HL, Choudhary SL, Prajapat AL, Choudhary R. Effect of integrated nutrient management on growth of Wheat (Triticum aestivum) cultivars. International Journal of Current Microbiology and Applied Sciences. 2017; 6(8):2369-2374.

2. Gomez KA, Gomez AA. Statistical procedures for agricultural research.2nd Edition. John Willey and Sons, New York, 1984, 680.

3. Jaga PK, Sharma S, Patel Y. Response of wheat (Triticum aestivum) to Azotobacter inoculation and 
nitrogen in soils of Vidisha, Madhya Pradesh. Annals of Plant and Soil Research. 2017; 19(1):42-45.

4. Kakraliya SK, Kumar N, Dahiya S, Kumar S, Yadav DD. Singh M. Effect of integrated nutrient management on growth dynamics and productivity trend of wheat (Triticum aestivum L.) under irrigated cropping system. Journal of Plant Development Sciences. 2017; 9(1):1115.

5. Parewa HP, Yadav J, Rakshit A, Choudhary A. Growth and yield attributes of wheat (Triticum aestivum L.) as affected by fertilizer levels, FYM and PGPR. International Journal of Chemical Studies. 2018; 6(5):4348.

6. Rather SA, Sharma NL. Effect of integrated nutrient management on yield and economics of wheat. An Asian Journal of Soil Science. 2009; 4(1):15-17.

7. Tejalben P, Patel KC, Patel VN. Effect of integrated nutrient management on yield attributes and yield of wheat (Triticum aestivum L.). 2017. International Journal of Chemical Studies. 2017; 5(4):1366-1369.

8. Singh V, Rana NS, Dhyani BP, Kumar R, Vivek Naresh RK, Kumar A. Influences of organic and inorganic fertilizers on productivity and soil fertility of wheat (Triticum aestivum L.) in Typic Ustochrept soil of Uttar Pradesh. Journal of Pharmacognosy and Phytochemistry. 2018; 7(1):260-265. 